DOI:

UDC: $141.7: 167.7 / 168.53$

Frol Revin,

National Pedagogical Dragomanov University

Kyiv, Ukraine

Postgraduate department of social philosophy, philosophy of education and educational policy

e-mail: frollrevin@gmail.com

ORCID: 0000-0002-7349-8079

\title{
COLLABORATIVE ACTION IN THE AGE OF SOCIAL MEDIA: DIGITAL CAPITAL, PUBLIC DISCOURSE AND POWER NETWORKS
}

The article explores potential consequences of utilizing digital networks viewed as a consolidating resource for generating trust and shared values necessary to establish credible commitments though e-driven cooperative pursuits. By taking advantage of research on web-facilitated collaborative algorithms I survey their importance for stimulating user civic engagement as well as highlight the resultant digital capital creation within the informational platforms in which they are embedded. Acknowledging the relevance of communication power in contemporary network societies (Castells) it becomes especially poignant to further analyze the fragmentation of authority brought about by ICT exposure rarely evident within the more conventional concentrated hubs of socio-political discourse. Specifically, I conjecture that compared to more traditional forms of public goods creation digital capital as a pioneering form of web-based interaction breads equally novel challenges for collective gains through the use of a virtually wholly decentralized architecture. With the development of ever more elaborate ways of communicating and connecting digital media allows us to make transparent and democratize the emergence of trend-generating communities that facilitate cooperation, discourage group bias while engendering trustworthiness across all levels of the social strata. Current research, thus, pursues the goal of scrutinizing if and how modern digital networks can be considered as effective, durable tools for accumulating social capital able to accrue critical mass necessary to give momentum to and spur its users towards solving collective action problems. While certain prominent theorists (Habermas, Bourdieu) can be interpreted to suggest that modern technology has had a detrimental effect on communal cohesion leading to slanted, overly manipulative depletion of networks through which it can take root and flow, the author has a more charitable outlook on the utility of digitally produced social capital. In particular, I contend that novel communication channels based on high speed broadband connection coupled with portable, on the go mobile communication have the capacity to create a broad societal nexus of trust by maintaining and multiplying bona fide social bonds.

Keywords: cooperation, collective action, virtual networks, ICT, social capital, digital capital, communication power, public sphere, fields of influence 
Анотація. Ревін Ф.Г. Сумісні дії у вік соціальних медіа: цифровий капітал, громадський дискурс і енергетичні мережі

У статті розглядаються наслідки використання цифрових мереж як консолідуючого ресурсу для формування довіри та спільних цінностей, завдяки використанню механізмів та інструментів сумісної електронної діяльності. Виходячи з дослідів алгоритмів взаємодії колаборативного онлайн простору, автор прослідковує їх важливість для стимулювання громадської активності користувачів, наголошуючи на продукуванні цифрового капіталу в рамках інформаційних платформ до яких вони інкорпоровані. 3 огляду на якість співробітництва в сучасних мережевих товариствах (Кастельс), стає принципово релевантним здійснити подальший аналіз інспірованої швидким розвитком інтернет технологій фрагментації механізмів контролю, що має місце в рамках більш авторитарних вузлових центрів зосередження соціально-політичного дискурсу. Зокрема, автор припускає, що, в порівнянні з більш традиційними методами вироблення суспільних благ, цифровий капітал як новаторська форма веб-кооперації, створює небачені виклики щодо формування колективної вигоди за рахунок використання цілковито децентралізованої архітектури взаємодії. Водночас, з розвитком все більш складних способів спілкування і сполуки, цифрові медіа дозволяють зробити прозорою і демократизувати появу тренд-генеруючих спільнот, що сприяють розвитку співпраці, перешкоджають колективній упередженості та стимулюють довірливі стосунки на всі рівнях соціальних прошарків. Даний дослід, отже, має на меті визначити доцільність цифрових мереж в якості ефективних інструментів накопичення соціального капіталу здатного акумулювати критичну масу та імпульс для заохочення користувачів до вирішення різноманітних проблем колективної дій. Незважаючи на те, що сучасні мережеві технології мають змогу чинити негативний вплив на колаборативну згуртованость, що веде до надмірно маніпулятивного виснаження інтерактивних моделей взаємин (Габермас, Бурдьє), більш оптимістичні потрактування, втім, свідчать на користь виробленого в цифровій формі соціального капіталу. Так, канали зв'язкузасновані на високошвидкісному доступі, в поєднанні з портативним, мобільним підключенням, шляхом підтримання та примноження сумлінних соціальних зв'язків, стрімко уможливлюють створення широкої діджиталізованої мережі довіри та кооперації.

Ключові слова: співпраця, колективні дії, віртуальні мережі, ІКТ, соціальний капітал, цифровий капітал, комунікаційна сила, публічна сфера, поля впливу

\section{Relevance of the research topic}

Present day digital media platforms permeate various spheres of life reaching far beyond the conventional scope of social, political and economic domain. With Web 2.0 long on the rise numerous e-facilitated campaigns have undoubtedly demonstrated the importance of Internet technologies for the organization and coordination of collective action in the absence of a more conventional centralized hub of sociopolitical 
activity. Lee Rainie, among others ${ }^{1}$, provides statistical data demonstrating a strong correlation between an individual's ability to influence the socio-political processes and the use of digital technology. In particular, what seems obvious is the underlying structure of digital activism perceived as a grassroots cooperative system empowering cause-driven groups of impactful actors to challenge the undesirable status quo. To achieve their goals these individuals form elaborate coordination mechanisms incorporating various sets of galvanizing instruments and symbolic practices. The former are employed as transformative tools applied to the social realm with tangible benefits for alienated and disenfranchised groups striving for social justice, inclusivity and participation ${ }^{2}$.

One can, specifically, point out the significant distinctions in the organizational structure of web-activism compared to non-digital campaigns whereby modern e-generated mass movements emerge and engender semi-anonymous collective action which does not necessarily require physical (or even ideological) proximity. Another evident benefit of online collectivity is that various social networks facilitate the search for and dissemination of information reducing the cost of access and political participation by providing ample opportunity not only for information acquisition but also for commenting, discussion and sharing. Perhaps the most prominent feature that virtual networks can boast is that they allow users to head and join social causes without direct participation in meetings and other related events. By stressing the importance of such large-scale exterritorial activist landscape for the success of digitally facilitated movements, researchers credit them with the creation of an alternative information space that allows to spread the core message while rallying and mobilizing its supporters.

Undoubtedly, widespread use of various social media platforms enhances and encourages greater inclusion, fosters diversity, promotes civic engagement and dialogue. All of this leads to an increased activity in collecting and processing information since digital communication channels can be shaped according to particular user expectations, agendas, and queries. More importantly, digital media allows for the creation and sustaining of favorable collective action conditions via a set of communication processes drawing a clear line between private and public sphere ${ }^{3}$. Having equal access to information, thus, qualifies e-based platforms as egalitarian means of communication with transparent networking. This principle of transparency can occur and is reinforced by the fact that all network participants can contribute to the

\footnotetext{
1 Rainie Lee et al., "Social media and political engagement. Washington, DC: Pew Internet and American LifeProject," last modified October 19, 2012, http://www.pewinternet.org/2012/10/19/social-media-and-political-engagement/.

2 Kavada Anastasia, "Creating the Collective: Social Media, the Occupy Movement and Its Constitution as a Collective Actor," Information, Communication \& Society 18, no. 8 (2015): 873, accessed July 28, 2020, doi: 10.1080/1369118X.2015.1043318.

3 Jennifer Earl and Kelly R. Garrett, "The new information frontier: toward a more nuanced view of social movement communication," Social Movement Studies 16, no. 4 (2017): 482, accessed August 3, 2020, doi: 10.1080/14742837.2016.1192028.
} 
common information pool serving not only as consumers but also through generating and validating the crucial informational field. The following procedure creates an incentive for additional deliberative selectivity which is aiding the overall community effort as it strives to establish conditions for the formation of concrete cooperative action. Based on this interpretation, we can note that virtual networks are a unique platform for consolidating the agendas of various groups of individuals based on their common nexus of shared intentions, interests and values resulting in coherent communicative interactions with a major synergistic effect4.

Electronic networks contribute to the increased demarcation and structuring of the online communication dimension whereby the creation of virtual communities oftentimes undergoes further transformation culminating in the formation of associations, activist groups, and public institutions. The latter fulfil yet another important function as they provide an opportunity to formally disseminate ideas, attract new members and coordinate their actions. As noted by T. M. Coopman with the rise of modern digital media we have a revolutionary concept where the physical and the virtual reciprocally influence each other by laying the foundation for the emergence of novel forms of socialization and social organization5. In particular, virtual networks allow to utilize previously unattainable forms of interaction bringing forth the expansion of collective action by uniting collaborators with matching professional qualities, personal and vocational aspirations.

A similar observation can be found in the works of Manuel Castells ${ }^{6}$ whose concept of network space rests on the flow of capital, information technology, network and symbolic interplay as the main driving forces that actors exchange depending on their proximity and integration into reallocation of resource centers. In such globally dominant technological infrastructure communication reigns supreme by determining this new interactive space almost as much as the railroads defined economic regions and national markets underpinned industrial economy. Castells views modern society as "a culture of real virtuality", a platform profoundly dominated by the wholly deterministic global communication systems. Consequently, nowadays sociopolitical reality is completely captured and fully immersed in the virtual images of an electronic world in which the externally displayed messages do not just appear on your screen as transmitted visual and symbolic experience, but themselves become the experience7. Accordingly, the Internet stimulates a plethora of multidirectional types of exchange which empower active users to rip unprecedented rewards of civic en-

4 Oksana Evsyukova, "Social networks and social capital as the drivers of service-oriented state development", Theory and practice of state governing 60, no. 1 (2018): 35, accessed August 12, 2020.

5 Ted M. Coopman, "Networks of Dissent: Emergent Forms in Media Based Collective Action," Critical Studies in Media Communication 28, no. 2 (2011): 164, accessed August 3, 2020, doi: 10.1080/15295036.2010.514934.

6 Manuel Castells, "Communication, power and counter-power in the network society," International Journal of Communication 1 (2007): 240, accessed May 2, 2020.

7 Manuel Castells, The Rise of the Network Society, With a New Preface. Vol. I: The Information Age: Economy, Society, and Culture. (Oxford, UK: Blackwell, 2009), 403. 
gagement and collective political action when compared to more conventional offline means of expression and participation.

At the same time, Bennett and Segerberg indicate that there are particularly effective gains to be had when random interpersonal networks become linked to technological platforms that provide for coordinated large scale collective action since such spontaneous networking allows you to more effectively ensure collaborative production and distribution of information and identities compared to the rigidly distributed content and bonds which are based solely on a stringent hierarchical organization8. Under these conditions there gradually forms a fixed nexus of interdependence between individuals whose stable cooperative relationships are strengthening the overall thrust of jointly undertaken civic pursuits. Distributed across various social media platforms these novel technological tools allow individuals to take advantage of the most suitable ways to voice their opinions, shaping and adapting message transmission amidst a constant flux of incoming data and rapidly changing external conditions.

Another consequence of network aggregating technologies is the phenomenon of "smart mobs" a term coined by Howard Reinhold to denote rapidly forming social movements acting in concert towards a social or a political agenda by taking advantage of e-technology and telecommunication platforms. Reinhold holds that modern communication channels are exceptionally purposed to lending its galvanizing resources to various crowd-cohesive intelligence units that are able to quickly rally around a common cause often relying (especially prior to 2000) on very little to no support from web-based social platforms. While an outstanding cooperative tool, smart mobs nonetheless have a host of negative consequences as they are especially susceptible to manipulation by unscrupulous third-party agitators, can suffer from gang mentality and have a dangerous potential for accelerating the spread of negative content9.

The lifeblood of any modern community is communication whereby actors with the greatest chance of influencing power are those whose messages generate the largest disseminating impact. As a probabilistic selection and transmission process, network communication is a synthesis of three major elements: information, relay and understanding. Hence, in order for communicative success to be secured the meaning of the message has to be accepted by the recipient as a prerequisite for subsequent reciprocal exchange10. Broadly defined communicative success is the result of attracting attention and motivation of other network participants. Again, it is important to stress that successful communication cannot fundamentally depend solely on the

${ }^{8}$ Lance W. Bennett and Alexandra Segerberg, "THE LOGIC OF CONNECTIVE ACTION," Information, Communication \& Society 15, no. 5 (2012): 745, accessed July 20, 2020, doi: 10.1080/1369118X.2012.670661.

9 Howard Rheingold, Smart Mobs: The Next Social Revolution. (New York: Basic Books, 2002), EPUB e-book, 24, 19.

${ }^{10}$ Hernando Rojas, Dhavan V. Shah, and Lewis A. Friedland, "A Communicative Approach to Social Capital," Journal of Communication 61, no. 4 (2011): 702, accessed June 29, 2020, doi: 10.1111/j.14602466.2011.01571.x. 
realization of its selective contents (meaning) with social impact of digital activity measured by calculating the number of subsequent response messages (comments) or other means of feedback. Conceptually, this entails that communicative capital while capable of being converted into other forms of reputational gains is qualitatively different from cultural or any other sort of capital and is therefore not reducible to it11.

This idea is supported by an acute observation of Jürgen Habermas who drew on a distinction between instrumental and communicative action. The latter was seen as a byproduct of a special democratizing dimension of the lifeworld where rational critical discourse led to wider inclusivity (irrespective of social power or standing for its validity) and quality of the collective decision-making bringing about an ideal speech situation. As individual units of collaborative discourse and a sure medium for reaching understanding "speech acts serve: a) to establish and renew interpersonal relations, whereby the speaker takes up a relation to something in the world of legitimate social orders; b) to represent states and events, whereby the speaker takes up a relation to something in the world of existing states of affairs; c) to manifest experiences that is, to represent oneself - whereby the speaker takes up a relation to something in the subjective world to which he has privileged access."12

Communicative action, thus, principally relies on citizens aiming to reach a common ground in contentious matters coordinating their actions by reasoned argument, consensus and through cooperation rather than undertaking purely strategic, goal-directed steps. Noticing an alarming pattern Habermas believed that a swift global growth of an overly capitalist attitude encroaching on all levels of the lifeworld would eventually spell degradation and doom for the ever diminishing character of the undiluted public sphere13. What especially seems to lend credence to this notion is a clear trend of how a more natural dialogue of the Habermasian type is presently (ICTs included) becoming increasingly formalized with rigorous rules of the communicative game supplanting a more organic set of deliberative practices.

All of this calls for a wholesale reevaluation of our rapidly shrinking discursive potential whereby previously accessible modes of the public forum viz., opinion forming, civic partnership and cooperation are swiftly becoming commodified. Suggesting that this radical new shift in the way we approach interpersonal communication was to a large degree accelerated by the rapid growth of commercial mass media, Habermas expressed dissatisfaction with our current move from a culture-debating society to

\footnotetext{
${ }^{11}$ Lynn Mandarano, Mahbubur Meenar, and Chris Steins, "Building Social Capital in the Digital Age of Civic Engagement," Journal of Planning Literature 25 (2010): 128, accessed May 15, 2020, doi: $10.1177 / 0885412210394102$.

${ }^{12}$ Jürgen Habermas, The theory of communicative action. Volume 1: Reason and the Rationalization of society. (Boston: Beacon Press, 1984), https://teddykw2.files.wordpress.com/2012/07/jurgen-habermas-theory-of-communicative-action-volume-1.pdf.

${ }^{13}$ Jürgen Habermas, The Structural Transformation of the Public Sphere: An Inquiry into a category of Bourgeois Society. (Cambridge: MIT Press, 1991), 162, http://egalitarianism.no/wp-content/ uploads/2014/10/The-Structural-Transformation-of-the-Public-Sphere.pdf.
} 
a culture-consuming one. The devastating results of such outright communicational consumerism are deftly observed by many social network researchers. Bjarki Valtysson remarks that when viewed from this vantage point, "the financial prowess of the market and the administrative power of the state act instrumentally and smother the communicative actions taking place in the lifeworld ... [where] ... the public sphere has ceased to be an inclusive communicative space for rational critical debate, and is now a venue for the instrumental rationale of the system."14

Hence, we can speak of the two fundamentally different approaches to making use of e-technologies in order to facilitate collaborative action. In the first case, the Internet is seen merely as a tool for coordination of social interaction that takes place in real physical space. A fitting example illustrating this would be all manner of public awareness affecting events, from peaceful flash mobs to protest rallies, organized with the help of virtual social networks such as Facebook, Twitter and other popular platforms. Accordingly, one can witness the impact of e-generated cohesion on politics, economics, education as well as the daily lives of regular users who perceive the web as an increasingly emancipated form of engagement that drastically modifies normative forms of interaction15. The second type of joint online transformation takes place solely within the virtual space where the goal is to achieve understanding of interpersonal rapport, establish proper communication and encourage informal informational exchange. It is this latter type of e-driven connective interlinkage which forms an interesting case for our current investigation.

Social bias inherent in certain virtual network formations, at first glance, appears paradoxical as it goes against the principal tenets of participant equality and communicative freedom expounded by the pioneers of Internet technology many of whom believed that digital interaction has the ability to neutralize offline micro and macro level imbalance without negating the existence of rigid social stratification that might otherwise inform other aspects of user behavior16. With the impact of digital media on the level of societal disparity a potentially fruitful exploratory avenue lies in applying Pierre Bourdieu's theory of social fields to the study of inequality appearing within virtual communities. In particular, his theory presupposes that any given medium's conventional utility is spread over a wide array of socially habitual practices regardless of its technical characteristics. In other words, modern Internet users, assign a flexible role to the technology in question. This most prominently manifests itself in Bourdieu's approach to photography whereby he believes that technological infrastructures do not just help you attain a fixed social goal, but are "socially shaped along with their meanings, functions, domains and use. Thus, they cannot come into

\footnotetext{
${ }^{14}$ Bjarki Valtysson, "Facebook as a digital public sphere: processes of colonization and emancipation," TripleC 10, no. 1 (2012): 77-78, accessed May 11, 2020, https://doi.org/10.31269/triplec. v10i1.312.

${ }^{15}$ Dounia Mahlouly, "Rethinking the Public Sphere in a Digital Environment: Similarities between the Eighteenth and the Twenty-First Centuries." ESharp 20, no. 6 (2013): 3-4.

16 Papacharissi Zizi, “The Virtual Sphere. The Internet as a Public Sphere," New Media and Society 4, no. 1 (2002): 11, accessed April 2, 2020, doi: 10.1177/14614440222226244.11.
} 
existence simply to fill a preexisting role, since the role itself is co-created with the technology by its makers and users. More importantly, this role is not a static function but something that can change over time for groups of people."17

Viewed through this lens, a social field is an arena of struggle between social actors (members of the digital community) for the right to reinvest the results of their online accumulated capital within task-oriented, field-specific limits (the boundaries of the virtual community) whereby the position of the actor in the hierarchy of a given field depends on the proportion of the total capital they have in defining authority access18. Actors occupying similar or close positions form a class with social field logic dictating a division of the totality of positions into two interlinked types based on the possession of class relational power. Since digital community participation principally comes in the form of information exchange, the ability to alter interpersonal communication (censoring debate platforms; editing posts of other users) can be interpreted as a form of direct constitutive power. Consequently, an inherent bias within a given online community exists as a division among users with and without control over other members' communication exchange and practice. It follows that digital inequality is embodied by an institute of moderators who exert legitimized symbolic censorship while representing the dominant e-stratum. With the old types of social inequality largely offset in the virtual space, the role of the classic forms of capital is likewise likely to be substantially reduced and/or significantly modified. Accordingly, cultural capital is digitized by means of users' internalized technological socialization directly corresponding to the scale, reach, and sophistication of their digital utilization patterns.

This Bourdieusian framework has documented empirical worth when applied to studies analyzing the status of online user activity scrutinizing the interplay between digital and other more concrete forms of capital. In particular, the former can undergo a reverse transformation into each of the three aforementioned forms of capital (cultural, social and informational) through unhindered professional networking, open access to public goods, and unrestricted dissemination of useful connections, skillsets and knowledge. ${ }^{19}$ This last point seems to hint at how the same kinds of ICT engagement can yield contrasting payoffs for differently skilled kinds of users. Indeed, the varying levels of digital habitus, access and literacy have shown to increase the gap in offline resource distribution mirroring visibly lower levels of economic and cultural capital. Hence, acquired expertise necessary for finding and assessing online data makes up one of the most prominent prerequisites for tech-savvy individuals whose digital adroitness serves as an advantageous precondition for the attainment of infor-

\footnotetext{
${ }^{17}$ Jonathan Sterne, "Bourdieu, Technique And Technology," Cultural Studies 17, no. 3-4 (2003): 372, accessed July 12, 2020, doi: 10.1080/0950238032000083863a.

${ }^{18}$ Gabe Ignatow, and Laura R. Pierre, "Bourdieu: theorizing the digital," Information, Communication \& Society 20 no. 7 (2017): 952, accessed June 11, 2020, doi: 10.1080/1369118X.2017.1301519.

${ }^{19}$ Massimo Ragnedda and Maria L. Ruiu, "Social capital and the three levels of digital divide," in Theorizing Digital Divides, ed. Massimo Ragnedda and Glenn Muschert (Abingdon: Routledge, 2017), 21-34.
} 
mational and operational superiority. Not only do better trained Internet users reap steady benefits by arriving at desired outcomes with less effort and significant time efficiency, but they are also able to utilize the various ICT capabilities in a more flexible and versatile manner compared to their less-skilled peers 20 . By seamlessly transitioning from one web resource to another these individuals are taking further advantage of the Internet's cohesion inducing platforms and algorithms via employing significantly more nuanced and productive tools available to those wishing to maximize their digital capital-enhancing potential.

\section{Conclusions}

Recapitulating on some of the major themes explored in the article we can attest to the uncanny ability of modern Internet technologies to provide a varied array of tools at the forefront of incentivizing trustworthy collective action. When applied to the digital realm, social capital manifests itself as form of transformative power affecting concrete and virtual inequalities. Accordingly, digital capital might be defined not only as a set of skills, competences and cooperative predispositions imbedded within a particular interconnected infrastructure, but serves the function of connecting social actors by creating new as well as reinforcing established relational power networks. Drastically reducing the costs of galvanizing joint collaborative pursuits, social media platforms through expedient socio-political communication allow to quickly reinvest beneficial know-how and information acquired online back into offline activity. Researchers entertaining Habermasian notions of speech acts within their theories seem to be espousing a more optimistic attitude towards the currently prevalent architecture and ethos of the online community that allows for unprecedented scale and volume of group solidarity and information exchange. Believing these latter achievements to reconcile well with the concept of the public sphere, proponents of e-generated networks are ready to set aside issues of collective identity, often overlooking underlying leadership structure dynamics and disregard participatory and motivational underpinnings that are at the crux of the formation of any social network. Thus, in our research we encountered models of online discourse that tend to take an uncritical view towards web fostered platform communication and cooperation that either intentionally bracket or altogether fail to differentiate between distinct types of discourse facilitators, neglecting to acknowledge the precise way freedom of expression is dependent on social platform architecture. With YouTube, Facebook and Twitter paving the way for new forms of collaborative practice while exercising unilateral authority one cannot disregard their massive influence as exclusive gatekeepers of the ever growing online discourse landscape. Without a doubt, the past 20 years have witnessed a revolution in ICT proliferation that had a profound democratizing effect on allowing the widest social strata to partake in the regional and global conversation by ushering an era of an almost utopian inclusivity and technological accessibility. Conversely, we have voices suggesting that the nowadays

\footnotetext{
${ }^{20}$ Laura Robinson, "A TASTE FOR THE NECESSARY: A Bourdieuian approach to digital inequality," Information, Communication \& Society 12, no.4 (2009): 488, accessed September 1, 2020, doi: 10.1080/13691180902857678.
} 
prevalent model of the digitally enabled user does not necessarily lead to the truly collective civic awareness, but is greatly removed from the genuinely collaborative habits of the past since the bulk of our interactions take place in fragmented, agenda-driven web-generated environments geared towards selectivity, all of which at best produces mitigated preferentialism. By skewing public opinion this algorithmic protocol tends to severely hinder discussion of public affairs whereby citizens are no longer required to freely deliberate, but are merely signaling their agreement or the lack thereof on a particular engineered status quo. Lastly, compromises to the depth of the public discourse are evident in the fact that users contributing online content (political or otherwise) have no means to affect the governing infrastructure leading to stifled and superficial civic activity. Reevaluation of the role digital platforms have come to play in our lives requires drawing a clear distinction between the medium and the media since the way social platforms are designed is conditioned by economic interests relying on users to provide personal content which in turn incentivizes the growth of purely commercial transactions significantly diluting the quality and merits of social interactions, collaborative potential and rational public discourse.

\section{References}

Bennett, Lance W., and Segerberg Alexandra. "The Logic of Connective Action. W. Lance Bennett \& Alexandra Segerberg (2012) THE LOGIC OF CONNECTIVE ACTION." Information, Communication \& Society 15, no. 5 (2012): 739-768. Accessed July 28, 2020. doi: 10.1080/1369118X.2012.670661.

Castells, Manuel. The Information Age: The Rise of the Network Society. Oxford: Blackwell, 2009.

Castells, Manuel. "Communication, power and counter-power in the network society." International Journal of Communication 1 (2007): 238-266. Accessed May 2, 2020. http://criticaltheoryindex.org/assets/CommunicationPowerandCounter-PowerintheNetworkSociety--Castells-Manuel.pdf.

Coopman, Ted M. "Networks of Dissent: Emergent Forms in Media Based Collective Action." Critical Studies in Media Communication 28, no. 2 (2011): 153-172. Accessed August 3, 2020. doi: $10.1080 / 15295036.2010 .514934$.

Earl, Jennifer, Kelly R. Garrett. "The new information frontier: toward a more nuanced view of social movement communication," Social Movement Studies 16, no. 4, (2017): 479493. Accessed August 3, 2020. doi: 10.1080/14742837.2016.1192028.

Evsyukova, Oksana "Social networks and social capital as the drivers of service-oriented state development." Theory and practice of state governing 60, no. 1 (2018): 32-39.

Ignatow, Gabe, and Laura R. Pierre. "Bourdieu: theorizing the digital." Information, Communication \& Society 20, no. 7 (2017): 950-966. Accessed June 11. 2020. doi: 10.1080/1369118X.2017.1301519.

Kavada, Anastasia. "Creating the Collective: Social Media, the Occupy Movement and Its Constitution as a Collective Actor." Information, Communication \& Society 18, no. 8 (2015): 872-886. Accessed July 28, 2020. doi: 10.1080/1369118X.2015.1043318. http://www.kbuapa.kharkov.ua/e-book/tpdu/2018-1/doc/1/05.pdf.

Habermas, Jürgen. The theory of communicative action. Volume 1: Reason and the Rationalization of society. Boston: Beacon Press, 1984, PDF e-book. https://teddykw2.files. 
wordpress.com/2012/07/jurgen-habermas-theory-of-communicative-action-volume-1. pdf.

Habermas, Jürgen. The Structural Transformation of the Public Sphere: An Inquiry into a category of Bourgeois Society. Cambridge: MIT Press, 1991. PDF e-book. http://egalitarianism.no/wp-content/uploads/2014/10/The-Structural-Transformation-of-the-PublicSphere..pdf.

Mahlouly, Dounia. "Rethinking the Public Sphere in a Digital Environment: Similarities between the Eighteenth and the Twenty-First Centuries." ESharp 20, no. 6 (2013): 1-21. Web address Accessed June 20, 2020. https://www.gla.ac.uk/media/Media_279211_smxx.pdf.

Mandarano, Lynn, Mahbubur Meenar, and Chris Steins. "Building Social Capital in the Digital Age of Civic Engagement." Journal of Planning Literature 25 (2010): 123-135. Accessed May 15, 2020. doi: 10.1177/0885412210394102.

Papacharissi, Zizi. “The Virtual Sphere. The Internet as a Public Sphere." New Media and Society 4 no. 1 (2002): 9-27. Accessed April 2, 2020. doi: 10.1177/14614440222226244.

Ragnedda, Massimo, and Maria L. Ruiu. "Social capital and the three levels of digital divide." In Theorizing Digital Divides, edited by Massimo Ragnedda and Glenn Muschert, 2134. Abingdon: Routledge, 2017.

Rainie, Lee, Arron Smith, Kay L. Schlozman, Henry Brady, and Sidney Verba. "Social media and political engagement. Washington, DC: Pew Internet and American Life Project." Last modified October 19, 2012. http://www.pewinternet.org/2012/10/19/ social-media-and-political-engagement/.

Rheingold, Howard. Smart Mobs: The Next Social Revolution. New York: Basic Books, 2003. EPUB e-book.

Robinson, Laura. "A TASTE FOR THE NECESSARY: A Bourdieuian approach to digital inequality." Information, Communication \& Society 12 no.4, (2009): 488-507. Accessed September 1, 2020. doi: 10.1080/13691180902857678.

Rojas, Hernando, Dhavan V. Shah, and Lewis A. Friedland. "A Communicative Approach to Social Capital." Journal of Communication 61, no. 4 (2011): 689-712. Accessed June 29, 2020. doi: 10.1111/j.1460-2466.2011.01571.x.

Sterne, Jonathan. "Bourdieu, Technique And Technology." Cultural Studies 17, no. 3-4 (2003): 367-389. Accessed July 12, 2020. doi: 10.1080/0950238032000083863a.

Valtysson, Bjarki. "Facebook as a digital public sphere: processes of colonization and emancipation." TripleC 10, no. 1 (2012): 77-91. Accessed May 11, 2020. https://doi. org/10.31269/triplec.v10i1.312. 